Herzschr Elektrophys $2021 \cdot 32: 412-413$ https://doi.org/10.1007/s00399-021-00803-1 Accepted: 9 August 2021

Published online: 13 August 2021

(c) Springer Medizin Verlag $\mathrm{GmbH}$, ein Teil von Springer Nature 2021

\section{In memoriam Norbert Zanker}

\author{
Seah Nisam ${ }^{1}$ Jörg Neuzner ${ }^{2}$ \\ ${ }^{1}$ Nisam Consultancy SPRL, Bierges, Belgium \\ ${ }^{2}$ B. Braun Ambulantes Herzzentrum Kassel, Kassel, Germany
}

Norbert Zanker (recent photo - • Fig. 1), a German biomedical engineer, who provided technical support and education to hundreds of Electrophysiologists and cardiac surgeons in Germany and internationally, passed away at his home (Uccle, Belgium), Saturday 24 July, 2021 after a long battle with cancer. Norbert was born in Augsburg, 9 April, 1957.

He earned his Nursing degree at the University of Heidelberg, where he went on to a Masters' degree in Anaesthesia and Intensive Care Medicine. Starting in 1977, he worked for six years as a surgical nurse in Heidelberg; thereafter, in the cardiac intensive care unit at City Hospital, Darmstadt. This was also the era when the "Automatic Implantable CardioverterDefibrillator" was introduced into clinical trials [1] - a technology/therapy that caught Norbert's interest. That interest led him to join the medical device division of Eli Lilly in 1987 (acquired in 1994 by Guidant Corporation, which in turn was acquired in 2006 by Boston Scientific Inc.). The Implantable Cardioverter Defibrillator (ICD) and its follow-up, Cardiac Resynchronization Therapy-Defibrillator (CRT-D), became the driving force during Norbert's 35-year career. In 1994, in recognition of his technical expertise and his fine collaboration with physicians, Norbert was appointed Manager of the "European Training Center" (ETC) at the Kerckhoff Clinic in Bad Nauheim. The photo (- Fig. 2) shows Norbert on the upper right, and the "faculty" - physicians and nurses at the KerckhoffClinic - at one of the first training sessions. Norbert and his family moved to Belgium in 2002, when the ETC was transferred to Diegem, Belgium, that year. Over 3000 physicians were trained on ICD therapy at the ETC. His many qualities-and appreciation within the company and from the physicians he helped-culminated in Norbert attaining "Senior Fellow" in Research and Development, and his vision led to the formation of a global technical services department in 2009. Starting in 2015, Norbert was a key member of the "Rhythm Management Medical Safety" organization, serving as a vital bridge between patients and physicians. As a reflection of Norbert's continual concern for patients, he became a key member of the company's "Patient Safety Advisory Board". Throughout his career, Norbert was known for his attention to detail, honesty, and firmness concerning product issues, always pushing for continuous product improvements-earning him respect and appreciation from key opinion leaders and professional societies. The referenced publication [2] illustrates his deep understanding of intricate de-

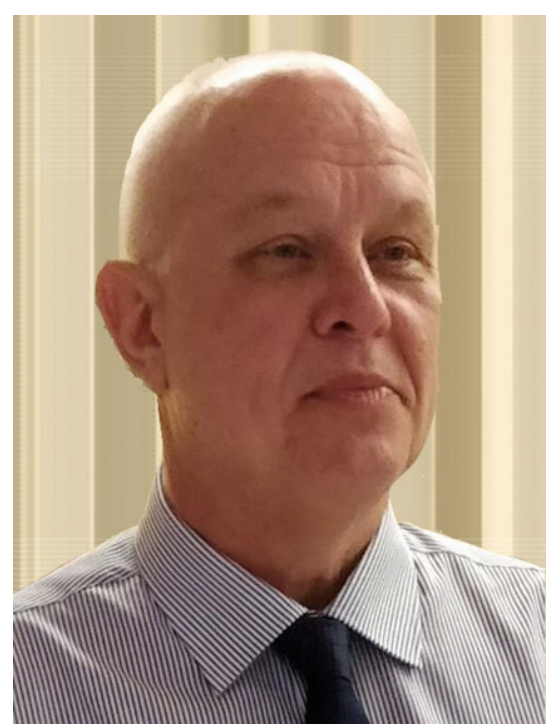

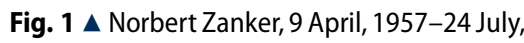
2021 


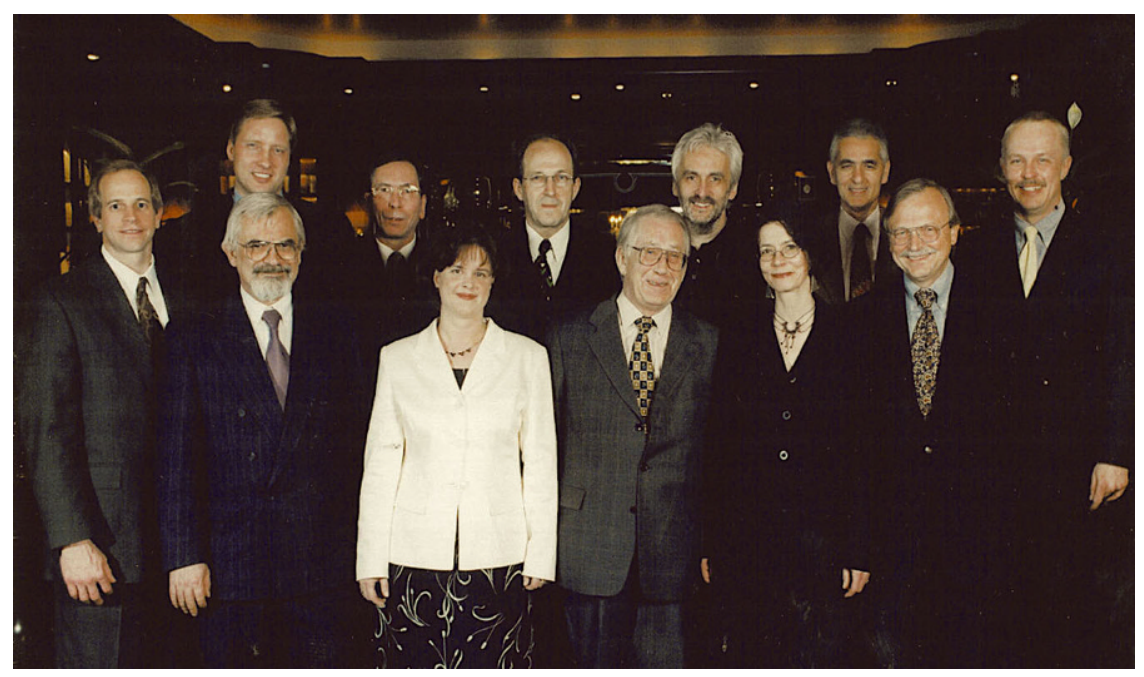

Fig. $2 \Delta$ Norbert Zanker, upper row, far right, flanked by physicians and nurses of the KerckhoffClinic

vice algorithms and patient-device interactions. He spent countless hours with physicians-by phone or often direct visits-on troubleshooting of device issues, and was known for never dodging difficult questions. Within the company-and the industry-he was the ultimate patient and physician advocate.

Norbert's favorite pastime was scuba diving, mastered to the point of becoming a licensed instructor. He had all the equipment needed for coral reef and even ship-wreck diving. He went with family and friends to exotic locations; Sharma El Sheikh was one of his favorite spots. According to one of his closest diving friends, "Norbert was the kind of person you can always trust and never giving any problem underwater, in short, the perfect buddy!".

This Memorium to Norbert Zanker must include some words about his warm, friendly personality. A deep sense of loyalty to his friends and loved ones. A great family man and devoted to his three children, always supporting and encouraging them. And having fun with them!

Norbert is survived by his children Yvonne, Jeanette, and Pascal, and their mother, Britta.

\section{Corresponding address}

\section{Seah Nisam, B.S.E.E.}

Nisam Consultancy SPRL

1, Ave des Tarins, 1301 Bierges, Belgium seahnisam@gmail.com

Acknowledgements. We wish to acknowledge Dr. Olaf Hedrich, V.P. Medical Safety (BSC)—Norbert's direct "boss" over the past 4.5 years, who provided us much of the detail we have reported above.

\section{Declarations}

Conflict of interest. S. Nisam and J. Neuzner declare that they have no competing interests.

This article does not contain any studies with human or animal subjects.

\section{References}

1. Mirowski M, Reid P, Mower M, Watkins Let al (1980) Termination of malignant ventricular arrhythmias with an automatic defibrillator in human beings. NEngl J Med 303:322-324

2. Zanker N, Schuster D, Gilkerson J, Stein K (2016) Tachycardia detection in ICDs by Boston scientific: algorithms, pearls, and pitfalls. Herzschr Elektrophys. https://doi.org/10.1007/s00399016-0454-2 